\title{
SENSITIVITY AND REPRODUCIBILITY OF POLYMERASE CHAIN REACTION ASSAYS FOR DETECTION OF HUMAN HERPESVIRUSES 6 AND 7
}

\author{
Svetlana Kozireva, Dmitrijs Užameckis, Mihails Bariševs, and Modra Murovska
}

August Kirchenstein Institute of Microbiology and Virology, Rīga Stradinš University, Rātsupìtes iela 5, Rīga, LV-1067, LATVIA

Contributed by Modra Murovska

\begin{abstract}
Human herpesvirus 6 (HHV-6) and 7 (HHV-7) are ubiquitous viruses that undergo latency and may become reactivated leading to cytomegalovirus reactivation, bone marrow suppression, nervous system dysfunction, graft-versus-host disease and increased mortality. The aim of this study was to identify the most sensitive and reproducible nPCR for detection of HHV-6 and $H H V-7$ infection and to evaluate the reproducibility of these assays in different laboratories. The sensitivity of the six previously published HHV-6 (one targeting hypothetical protein Bgp009 gene, two - large tegument protein gene, one - major binding protein gene and two targeting hypothetical Bgp071 protein gene) and four HHV-7 (targeting nuclear phosphoprotein, tegument phosphoprotein, large tegument protein and immediately early $A$ transactivator gene) nPCRs was determined. The most sensitive HHV-6 nPCR was targeted Bgp071 protein gene, which could detect 5 genomic copies of HHV-6. The most sensitive and reproducible HHV-7 nPCR assay, targeting nuclear phosphoprotein gene, could detect 1 genomic copy of HHV-7. The reproducibility of the selected HHV-6 and HHV-7 nPCRs was evaluated in five different laboratories. The results obtained in all laboratories were identical to our results, confirming that these nPCRs are useful as assays for molecular diagnostics of HHV-6 and HHV-7 infection.
\end{abstract}

Key words: $H H V-6, H H V-7$, infection, molecular diagnostic, nested PCR.

\section{INTRODUCTION}

Human herpesviruses type 6 (HHV-6) and type 7 (HHV-7) belong to the Roseolovirus genus within the beta-herpesvirus subfamily. Both of the viruses are highly prevalent in the healthy population, establishing latency in the human host after the primary infection, and can become reactivated in immunosuppressive individuals (Chapenko et al., 2001; Kozireva et al., 2001).

HHV-6, initially termed human B-lymphotropic virus, was first isolated in 1986 from patients with various lymphoproliferative disorders (Salahuddin et al., 1986). There are two distinct variants of HHV-6 - HHV6A and HHV-6B (Ablashi et al., 1993). With the exception of a few genes or regions, the coding sequences of HHV-6A and HHV-6B are identical for more than $90 \%$ (Isegawa et al., 1999). HHV-6 (A and $\mathrm{B}$ variants) reactivation occurs in approximately $50 \%$ of bone marrow and solid organ transplant recipients. The consequences of HHV-6 reactivation include cytomegalovirus (CMV) reactivation, bone marrow suppression, central nervous system dysfunction, idiopathic pneumonitis, severe graft-versus-host disease, hepatitis fulminant liver failure and increased mortality (Chapenko et al., 2001; Caselly et al., 2007).

$\mathrm{HHV}-7$, first isolated from CD4+ T cells of healthy individuals in 1990, has been implicated as a cause of neurological manifestations and can act as a cofactor for HHV-6 activation and CMV disease development in transplant patients (Frenkel et al., 1990; Chan et al., 2004; Caselly et al., 2007).

The lack of a standardised assay for detection of HHV-6 and HHV-7 DNA can lead to discordant results among investigators on potential association of these viruses with the diseases. The sensitivity of the assay is a very important issue, considering that HHV-6 and HHV-7 generally remain cell-associated and that the detection of cell-free HHV-6 and HHV-7 in biological samples can be clinically meaningful. Moreover, the routine diagnostic of HHV-6 and HHV-7 infections in Latvia is lacking. The aim of this study was to identify the most reliable and sensitive nested polymerase chain reaction (nPCR) assays for detection of HHV-6 and HHV-7. We compared the sensitivity of six nPCR assays for HHV-6 and four nPCR assays for HHV-7 and determined the reproducibility of the selected nPCR assays in five different laboratories. 


\section{MATERIALS AND METHODS}

Evaluation of sensitivity and reproducibility of the nPCR assays. Quantitative viral HHV-6A (strain GS), HHV-6B (strain Z-29) DNA controls and DNA from HHV-7 (strain H7-4) infected SupT1 cell line (50 ng/ $\mu \mathrm{l} \mathrm{rep-}$ resenting $\sim 25 \times 10^{6}$ copies of the virus/ $\mu$ l) (MacKenzie et al., 2001) were purchased from Advanced Biotechnologies Inc. (Columbia, MD).

Six separate nPCR assays - one targeting the hypothetical protein Bgp009 (Bgp009) gene, two targeting large tegument protein (LTP) gene, one targeting major binding protein (MBP) gene and two targeting hypothetical Bgp071 protein gene (Bgp071) - were used for detection of HHV-6. Four separate nPCR assays targeting nuclear phosphoprotein (NPP), tegument phosphoprotein (TPP), large tegument protein (LTP) and immediately early A transactivator (IE-A) genes, respectively, were used for detection of HHV-7. In all cases, the amplification reactions were performed in a volume of $50 \mu \mathrm{l}$ as previously described (Hall et al., 1994; Challoner et al., 1995; Secchiero et al., 1995; Ueda et al., 1996; Chan et al., 1999; Gonelli et al., 2001) and the amplification products were analysed by agarose gel electrophoresis followed by ethidium bromide staining.

To determine the minimal detection limit of these HHV-6 and HHV-7 nPCR assays, serial dilutions of HHV-6 and HHV-7 commercial DNA controls were used as a template for PCR amplification. To determine reproducibility of HHV-6 and HHV-7 nPCRs each nPCR assay was tested by using dilution series of HHV-6 and HHV-7 DNAs in 10 repeats for each dilution.

Interlaboratory evaluation of reproducibility of the two selected HHV-6 and HHV-7 nPCR assays. Blood samples from 20 renal transplant patients, as well as from 20 patients with colorectal cancer, were tested at least two times in our laboratory for the presence of HHV-6 and HHV-7 genomic sequences using two of the most sensitive nPCR assays. The investigation was carried out with approval of Ethics Committee of Rīga Stradiňš University and all patients gave their informed consent prior to the examination.

DNA from the HOS cell line was used as a negative amplification control. DNA was purified from peripheral blood leukocytes by proteinase $\mathrm{K}$ digestion and extraction by standard phenol-chloroform technique as described before (Murovska et al., 2000).

Each of the five testing laboratories (Latvian State Blood Centre, Latvian State Agency for Tuberculosis and Lung Diseases, National Diagnostic Centre of Food and Veterinary Service, Latvian Biomedical Research and Study Centre, Genera Ltd.) had received six coded samples: four clinical DNA samples, one positive amplification control (containing 20 copies of the entire virus/ $\mu \mathrm{l}$ ) and one negative amplification control (DNA from HOS cell line). All samples were arranged in a blinded fashion. Each laboratory was using the same amplification protocols (including their own non-template or PCR reagent control) to confirm the reproducibility of these assays.

Sequencing analysis. The amplimers, obtained from three HHV-6 positive patients and three HHV-7 positive patients by using the selected Bgp071 HHV-6 and NPP HHV-7 $\mathrm{nPCR}$ assays were cloned into a cloning vector $\mathrm{pTZ57R/T}$ by using the InsTAclone ${ }^{\mathrm{TM}}$ PCR Cloning Kit (Fermentas, Lithuania) and sequenced on an ABI 310 capillary electrophoresis system (Applied Biosystems, Foster City, CA) using the BigDye terminator v3.1 sequencing kit. The sequences were further analysed with the BLAST alignment programme.

\section{RESULTS}

Evaluation of the sensitivity and intralaboratory reproducibility of different HHV-6 and HHV-7 nPCR assays. We compared the performance of six different nPCR assays targeting four different HHV-6 genes and four nPCRs assays targeting four different HHV-7 genes by testing the serial dilutions of HHV-6 and HHV-7 commercial DNA controls (Table I).

The HHV-6 nPCRs targeting Bgp009, LTP and Bgp071 genes had the same sensitivity and allowed to detect 10 genome copies of both A and B variants of HHV-6. The sensitivity of HHV-6 nPCR targeting MBP gene was 50 copies for both HHV-6 variants, nPCR with the second set of primers targeting LTP gene -25 copies of HHV-6A and 50 of HHV-6B, respectively, while the nPCR assay with the second set of primers targeting Bgp071 gene was the most sensitive and could detect five genome copies of both A and B variants of HHV-6 (Fig. 1 and Table 2). The sensitivity of HHV-7 LTP and TPP nPCR assays was five copies and one copy for nPCRs targeting IE-A transactivator and NPP genes (Fig. 2 and Table 2).

Table 1

nPCR ASSAYS USED IN THE STUDY

\begin{tabular}{|c|c|c|c|}
\hline Virus & Target & \begin{tabular}{|c|} 
nPCR prod- \\
uct length
\end{tabular} & Reference \\
\hline \multirow[t]{4}{*}{ HHV-6 } & $\begin{array}{l}\text { Hypothetical Bgp009 } \\
\text { protein gene }\end{array}$ & $151 \mathrm{bp}$ & Hall et al., 1994 \\
\hline & $\begin{array}{l}\text { Large tegument protein } \\
\text { gene }\end{array}$ & $\begin{array}{l}751 \mathrm{bp} \\
658 \mathrm{bp}\end{array}$ & $\begin{array}{l}\text { Ueda } \text { et al., } 1996 \\
\text { Secchiero } \text { et al., } 1994\end{array}$ \\
\hline & $\begin{array}{l}\text { Major binding protein } \\
\text { gene }\end{array}$ & 189 bp & Challoner et al., 1995 \\
\hline & $\begin{array}{l}\text { Hypothetical Bgp071 } \\
\text { protein gene }\end{array}$ & $\begin{array}{l}130 \mathrm{bp} \\
258 \mathrm{bp}\end{array}$ & $\begin{array}{l}\text { Chan et al., } 1999 \\
\text { Secchiero et al., } 1995\end{array}$ \\
\hline \multirow[t]{4}{*}{ HHV-7 } & $\begin{array}{l}\text { Nuclear phosphoprotein } \\
\text { gene }\end{array}$ & $124 \mathrm{bp}$ & Chan et al., 1999 \\
\hline & $\begin{array}{l}\text { Tegument } \\
\text { phosphoprotein gene }\end{array}$ & $119 \mathrm{bp}$ & Gonelli et al., 2001 \\
\hline & $\begin{array}{l}\text { Large tegument protein } \\
\text { gene }\end{array}$ & $447 \mathrm{bp}$ & Gonelli et al., 2001 \\
\hline & $\begin{array}{l}\text { Immediately early A } \\
\text { transactivator gene }\end{array}$ & $140 \mathrm{bp}$ & Gonelli et al., 2001 \\
\hline
\end{tabular}




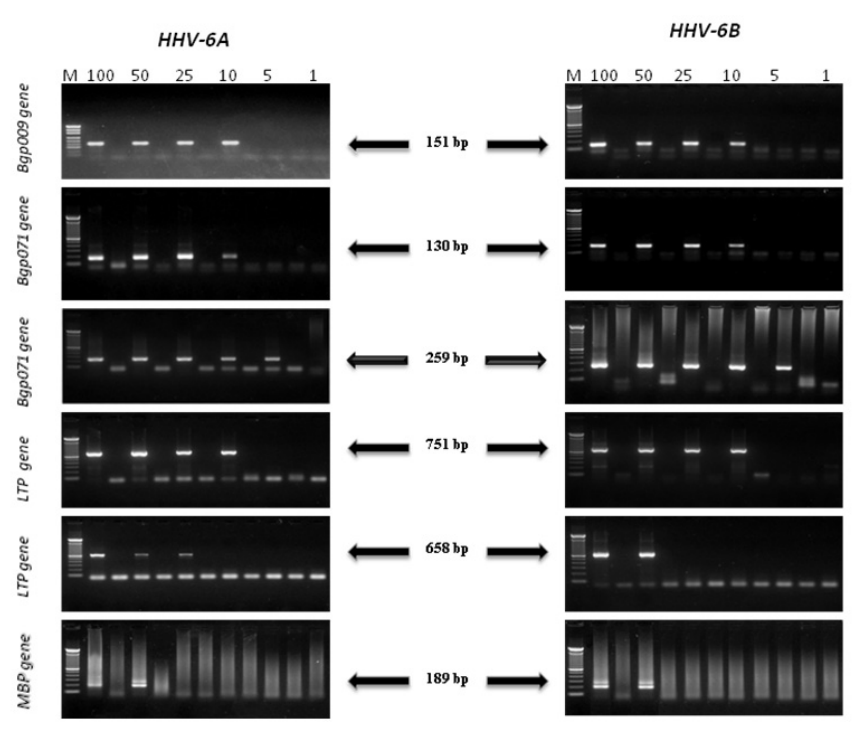

Fig. 1. Sensitivity of six nPCR assays for HHV-6 detection.

Lane M, pUC19 DNA/MspI (HpaII) (Fermentas, Lithuania) for HHV-6A Bgp009 gene and 100 bp DNA Ladder (Invitrogen, USA) for all others; lanes $100,50,25,10,5$ and 1 - copy number of HHV-6 DNA per reaction.

Table 2

SENSITIVITY OF nPCR ASSAYS USED IN THE STUDY

\begin{tabular}{c|c|c}
\hline Virus & \multicolumn{1}{c}{ Target gene } & $\begin{array}{c}\text { Sensitivity } \\
\text { (copies/reaction) } \\
\text { HHV-6 variants A/B }\end{array}$ \\
\hline HHV-6 & Hypothetical Bgp009 protein gene & $10 / 10$ \\
& Large tegument protein & $10 / 10$ \\
& Major binding protein gene & $25 / 50$ \\
& Hypothetical Bgp071 protein gene & $50 / 50$ \\
HHV-7 Nuclear phosphoprotein gene & $10 / 10$ \\
& Tegument phosphoprotein gene & $5 / 5$ \\
& Large tegument protein gene & 5 \\
Immediately early A transactivator & 5 \\
gene & 1
\end{tabular}

The reproducibility of each $\mathrm{nPCR}$ assay was examined by testing dilution series of HHV-6 and HHV-7 DNAs in 10 repeats for each dilution. The results showed that all six HHV-6 nPCRs had the same reproducibility (10 of 10 repeats). The identical reproducibility was observed also using HHV-7 specific nPCRs targeting TPP, LTP and NPP genes (10 out of 10 replicates), while the reproducibility of nPCR targeting EI-A gene of HHV-7 was detected in 8 of 10 repeats.

Interlaboratory reproducibility of the selected HHV-6 and HHV-7 nPCR assays. Five different laboratories using two of the most sensitive and reproducible HHV-6 and HHV-7 nPCR assays were asked to participate in this study. Each laboratory received different sets of six coded samples and performed the HHV-6 and HHV-7 analyses by the pro-

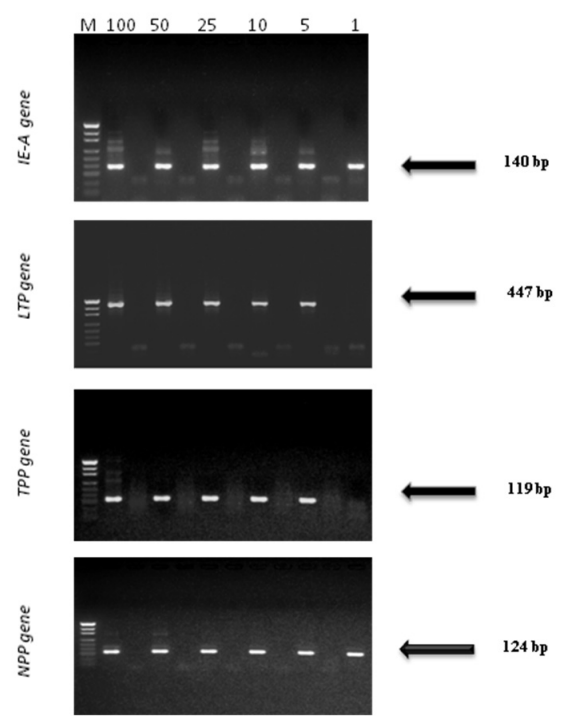

Fig. 2. Sensitivity of four nPCR assays for HHV-7 detection.

Lane M, pUC19 DNA/MspI (HpaII) (Fermentas, Lithuania); lanes 100, 50, $25,10,5$ and 1 - copy number of HHV-6 DNA per reaction.

tocols provided by our (reference) laboratory. Upon completion, each laboratory was asked to send its results to the project coordinator. In all five laboratories any false-positive results for the HHV-6 and HHV-7 negative samples and controls as well as any negative results for HHV-6 and HHV-7 positive samples and controls were reported for these two assays. The obtained results confirmed the high reproducibility of these two nPCRs for detection of HHV-6 and HHV-7.

Sequencing analysis. Three amplimers from three HHV-6 positive renal transplant patients obtained by using the selected HHV-6 nPCR assay that could detect five genomic copies and targeted Bgp071 gene were cloned and analysed by sequencing. The obtained sequences were compared to all published genomic sequences of HHV-6: HHV-6A strain U1102 (X83413.1), HHV-6B strain Z29 (AF_157706.1) and HHV6B strain HST (AB_021506.1). Ten nucleotide substitutions were observed compared to the prototype genomic sequence of HHV-6A strain U1102, and two nucleotide substitutions - compared to the prototype genomic sequence of HHV-6B strain Z29, but the nucleotide sequences of all three patients were identical to genomic sequence of HHV-6B strain HST (Fig. 3).

Three amplimers from three HHV-7 positive patients with colorectal cancer obtained by selected HHV-7 nPCR which could detect 1 genomic copy of HHV-7 and targeted NPP gene, were also cloned and analysed by sequencing. No nucleotide substitutions were found in these patients and the nucleotide sequences of all three patients were identical to prototype HHV-7 strain RK (NC_001716).

\section{DISCUSSION}

HHV-6 and HHV-7 are known as etiological agents of exanthema subitum (Caselly et al., 2007). Both HHV-6 and 


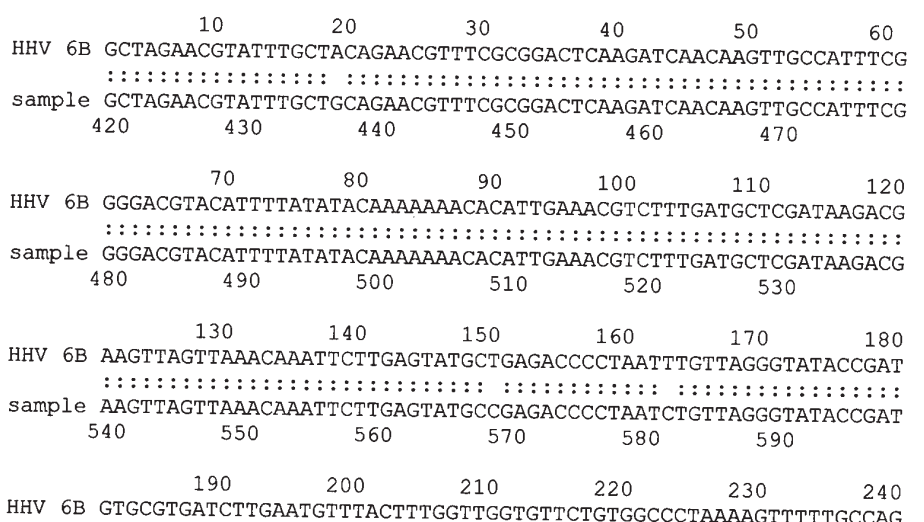

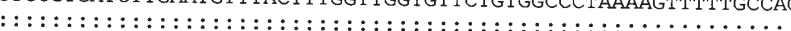
sample GTGCGTGATCTTGAATGTTTACTTTGGTTGGTGTTCTGTGGCCCTAAAAATTTTGCCA $600610 \quad 620 \quad 630 \quad 640 \quad 650$ 250

HHV $6 \mathrm{~B}$ TCAGACAGTTGTTTCGGAT $:::::::::::::::::::::$ :

sample TCAGACAGTTGTTTCGGAT $660 \quad 670$

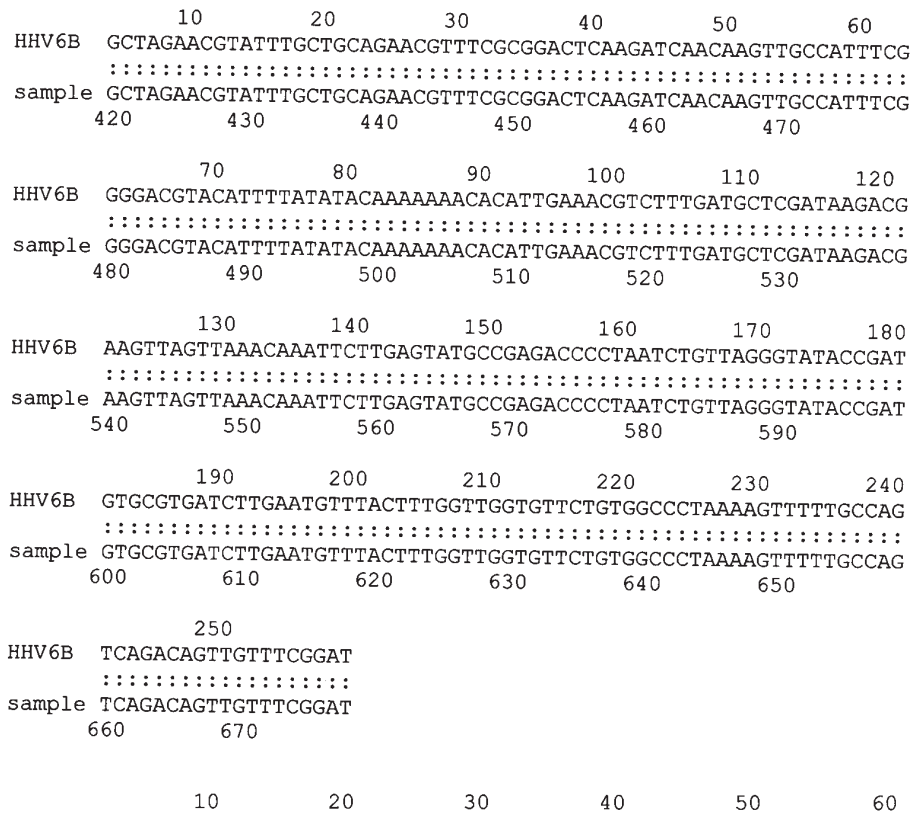
HHV 6A GCTAGAACGTATTTGCTGCAGAACGTTTTGCGGACTCAAGATCAACAAGTTGCCATTTCG

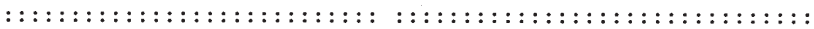
sample GCTAGAACGTATTTGCTGCAGAACGTTTCGCGGACTCAAGATCAACAAGTTGCCATTTCG $420 \quad 430 \quad 440 \quad 450 \quad 460 \quad 470$

$\begin{array}{llllll}70 & 80 & 90 & 100 & 110 & 120\end{array}$

HHV 6A GGGAAGTACATTTTGTATACAAAAAAACACATTGAAACGTCTTTGATGATCGATAAGACG

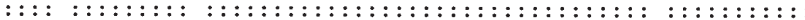
sample GGGACGTACATTTTATATACAAAAAAACACATTGAAACGTCTTTGATGCTCGATAAGACG $\begin{array}{lllll}480 & 490 & 500 & 510 & 520\end{array}$

$\begin{array}{llllll}130 & 140 & 150 & 160 & 170 & 180\end{array}$ HHV 6A AAGTTAGTTAAAAAAATTCTCGAGTATGCCGAGACCCCTAATCTGTTAGGATATACCGAT

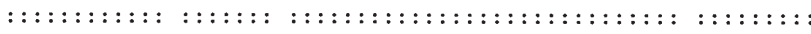
sample AAGTTAGTTAAACAAATTCTTGAGTATGCCGAGACCCTAATCTGTTAGGGTATACCGAT $\begin{array}{lllll}540 & 550 & 560 & 570 & 580\end{array}$

$\begin{array}{lllll}190 & 200 & 210 & 220 & 230\end{array}$

HHV 6A GTGCGTGATCTTGAATGTTTACTTTGGTTAGTGTTTTGTGGTCCTAAAAGTTTTTGCCAG

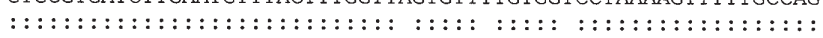
sample GTGCGTGATCTTGAATGTTACTTTGGTTGGTGTTCTGTGGCCCTAAAAGTTTTTGCCAG $\begin{array}{lllll}600 & 610 & 620 & 630 & 640\end{array}$

HHV 6A TCAGACAGTTGTTTCGGAT

$:::::::::::::::::::::$ :

sample TCAGACAGTTGTTTCGGAT

$660 \quad 670$

Fig. 3. Nucleotide sequence alignment of 258 bp HHV-6 PCR amplified fragment against two HHV-6B strains - Z29 (Accession number AF_157706.1) and HST (Accession number AB_021506.1) and HHV-6A strain U1102 (Accession number X83413.1). 
HHV-7 infect cells of the immune system and can modulate their functions (Lusso, 2006). Both HHV-6 and HHV-7 are highly prevalent in the healthy population, after primary infection the viruses establish lifelong latency and the pathogenic potential of reactivated virus ranges from asymptomatic infection to severe diseases in immunosuppressed patients, especially in transplant recipients (Caselly et al., 2007). PCR-based assays have been recognised as a sensitive and specific method for molecular detection and identification of HHV-6 and HHV-7. Different nPCR assays for detection of HHV-6 and HHV-7 have been reported, but none of these assays has been compared systematically. There also are described various assays for quantitative HHV-6 and HHV-7 detection, based on TaqMan PCR technology, but those assays are very expensive, limiting their general use. Chronic HHV-6 and HHV-7 infections are difficult to detect since there is very little free virus circulating in serum. Therefore, there is urgent need for very sensitive diagnostic assays and for studies that can prove or disprove the importance of these viral infections in various pathological processes.

In this study we evaluated the sensitivity of the six previously described nPCRs assays for detection of HHV-6 and 4 nPCRs for detection of HHV-7. All six nPCR assays for HHV-6 can detect both HHV-6 variants. The most sensitive nPCR for HHV-6 detection was nPCR with primers targeting the Bgp071 gene. The minimal amount that could be reproducibly detected by this $\mathrm{nPCR}$ assay was five genomic copies of HHV-6 (A and B). The most sensitive and reproducible nPCR assay for detection of HHV-7 was nPCRs with primers targeting NPP gene. These assays could detect one copy of HHV-7.

HHV-6 specific amplimers (Bgp071 gene) of three renal transplant patients as well as HHV-7 specific amplimers (NPP gene) of three patients with colorectal cancer were cloned and analysed by sequencing. The results of sequencing of HHV-6 and HHV-7 positive amplimers confirmed the presence of HHV-6 or HHV-7 genomic sequences in these samples and demonstrated that all three patients had HHV-6B strain HST, since their nucleotide sequences were identical to this strain of HHV-6. All three HHV-7 positive patients had a nucleotide sequence identical to prototype HHV-7.

Taking into account that nPCR assays are associated with a high risk of contamination, the reproducibility of the most sensitive nPCRs, targeting to Bgp071 gene of HHV-6 and NPP gene of HHV-7, was evaluated in five different laboratories using the same nPCR protocol and DNA samples proved positive or negative in our laboratory. The identical results obtained in all five laboratories confirmed the reproducibility of these nPCR assays for HHV-6 and HHV-7 detection. No evidence of contamination was observed using these nPCR assays in all five laboratories indicating that these nPCR are useful as assays for detection of HHV-6 and HHV-7.
The pathogenesis of HHV-6 and HHV-7 infections, the methods for their diagnosis, as well as the evaluation of antiviral drugs and strategies for their prevention and treatment are now the subject of extensive research. Our study showed that the HHV-6 nPCR with primers targeted to Bgp071 gene and HHV-7 nPCR with primers targeted to NPP gene are sensitive and reproducible assays and may be useful for molecular diagnostics of HHV-6 and HHV-7 infection. Moreover, this study emphasises the importance of performing multi-institution experiments to provide a coherent basis for comparing results and to motivate standardisation of the methods.

\section{ACKNOWLEDGEMENTS}

The work was supported by the National Research Programme in Medicine 2006-2009, project No. 11, „Immunomodulating viruses: strategy of infection diagnostics and opportunities to correct the treatment".

\section{REFERENCES}

Ablashi, D.V., Agut, H., Berneman, G., Campadilli-Fiume, G., Carrigan D., Ceccerini-Nelli, L., Chandran, B., Chou, S., Collandre, H., Cone, R., Collandre, H., Cone, R., Dambaugh, T., Dewhust, S., DiLuca, D., Foą-Tomasi, L., Fleckeinstein, B., Frenkel, N., Gallo, R., Gomples, U., Hall, C., Jones, M., Lawrence, G., Martin, M., Montagnier, L., Neipel, F., Nicholas, J., Pellet, P., Razzaque, A., Torrelli, G., Thomson, B., Salahuddin, S., Wyatt, L., Yamanishi, K. (1993). Human herpesvirus-6 strain groups: A nomenclature. Arch. Virol., 129(1-4), 363-366.

Caselly, E., Di Luca, D. (2007). Molecular biology and clinical associations of Roseolaviruses herpesvirus 6 and human herpesvirus 7. New Microbiol., 30(3), 173-178.

Challoner, P.B., Smith, K.T., Parker, J.D., MacLeod, D.L., Coulter, S.N., Rose, T.M., Schultz, E.R., Bennett, J.L., Garber, R.L., Chang, M., Schad, P.A., Stewart, P.M., Nowinski, R.C., Brown, J.P., Burmer, G.C. (1995). Plaque-associated expression of human herpesvirus 6 in multiple sclerosis. Proc. Natl. Acad. Sci. USA, 92(16), 7440-7444.

Chan, P.K., Ng, H.K., Cheng, A.F. (1999). Detection of human herpesviruses 6 and 7 genomic sequences in brain tumours. J. Clin. Pathol., 52(8), 620-623.

Chan, P.K., Li, C.K., Chik, K.W., Lee, V., Shing, M.M., Ng, K.C., Cheung, J.L., Fok, T.F., Cheng, A.F. (2004). Risk factors and clinical consequences of human herpesvirus 7 infection in paediatric haematopoietic stem cell transplant recipients. J. Med. Virol., 72(4), 668-674.

Chapenko, S., Folkmane, I., Tomsone, V., Kozireva, S., Bicans, J., Amerika, D., Rozentals, R., Murovska, M. (2001). Infection of beta-herpesviruses (CMV, HHV-6, HHV-7): Role in postrenal transplantation complications. Transplant. Proc., 33(4), 2463-2464.

Frenkel, N., Schirmer, E.C., Wyatt, L.S., Katsafanas, G., Roffman, E., Danovich, R.M., June, C.H. (1990). Isolation of a new herpesvirus from human CD4+ T cells. Proc. Natl. Acad. Sci. USA, 87(2), 748-752.

Gonelli, A., Boccia, S., Boni, M., Pozzoli, A., Rizzo, C., Querzoli, P., Cassai, E., Di Luca, D. (2001). Human herpesvirus 7 is latent in gastric mucosa. $J$. Med. Virol., 63(4), 277-283.

Hall, C.B., Long, C.E., Schnabel, K.C., Caserta, M.T., McIntyre, K.M., Costanzo, M.A., Knott, A., Dewhurst, S., Insel, R.A., Epstein, L.G. (1994). Human herpesvirus-6 infection in children. A prospective study of complications and reactivation. New Engl. J. Med., 331(7), 432-438.

Isegawa, Y., Mukai, T., Nakano, K., Kagawa, M., Chen, J., Mori, Y., Sunagawa, T., Kawanishi, K., Sashihara, J., Hata, A., Zou, P., Kosuge, H., Yamanishi, K. (1999). Comparison of the complete DNA sequences of human herpesvirus 6 variants A and B. J. Virol., 73(10), 8053-8063. 
Kozireva, S., Nemceva, G., Danilane, I., Pavlova, O., Blomberg, J., Murovska, M. (2001). Prevalence of blood-borne viral infections (cytomegalovirus, human herpesvirus-6, human herpesvirus-7, human herpesvirus-8, human T-cell lymphotropic virus-I/II, human retrovirus-5) among blood donors in Latvia. Ann. Hematol., 80(11), 669-673.

Lusso, P.L. (2006). HHV-6 and the immune system: Mechanisms of immunomodulation and viral escape. J. Clin. Virol. 37(Suppl. 1), S4-S10.

MacKenzie, J., Gallagher, A., Clayton, R.A., Perry, J., Eden, O.B., Ford, A.M., Greaves, M.F., Jarrett, R.F. (2001). Screening for herpesvirus genomes in common acute lymphoblastic leukemia. Leukemia, 15(3), 415-421.

Murovska, M., Lejniece, S., Kozireva, S., Koulikovska, M., Yin, H., Blomberg, J. (2000). Human retrovirus 5 sequences in peripheral blood cells from patients with B-cell non-Hodgkin's lymphoma. Int. J. Cancer, 85(6), 762-770.

Salahuddin, S.Z., Ablashi, D.V., Markham, P.D., Josephs, S.F., Sturzenegger S., Kaplan, M., Halligan, G., Biberfeld, P., Wong-Staal, F., Kramarsky, B., Gallo, R.C. (1986). Isolation of a new virus, HBLV, in patients with lymphoproliferative disorders. Science, 234(4776), 596-601.

Secchiero, P., Carrigan, D.R., Asano, Y., Benedetti, L., Crowley, R.W., Komaroff, A.L., Gallo, R.C., Lusso, P. (1995). Detection of human herpesvirus 6 in plasma of children with primary infection and immunosuppressed patients by polymerase chain reaction. J. Infect. Dis., 171(2), 273-280.

Ueda, T., Miyake, Y., Imoto, K., Hattori, S., Miyake, S., Ishizaki, T., Yamada, A., Kurata, T., Nagai, T., Suga, S., Asano, Y. (1996). Distribution of human herpesvirus 6 and varicella-zoster virus in organs of a fatal case with exanthem subitum and varicella. Acta Paediatr. Jpn., 38(6), 590-595.

Received 10 March 2009

\section{DAŽĀDU POLIMERĀZES ĶĒDES REAKCIJU JUTĪBA UN REPRODUCĒJAMĪBA CILVĒKA 6. UN 7. HERPESVĪRUSA NOTEIKŠANAI}

Cilvēka 6. un 7. herpesvīruss (HHV-6 un HHV-7) ir plaši izplatîti vīrusi, kas pēc primārās infekcijas saglabājas latentā stāvoklī visa mūža garumā. Pie dažādiem imūnsupresīviem stāvokḷiem tie var tikt reaktivēti un, savukārt, izsaukt citomegalovīrusa reaktivāciju, kaula smadzenu supresiju, nervu sistēmas disfunkciju, "transplantāts pret saimnieku" slimību un pieaugošu mirstību. Šì darba mērkis bija atrast visjutīgākās reproducējamās polimerāzes k,ēdes reakcijas (polymerase chain reaction, $P C R$ ) ar iekšējo praimēšanu HHV-6, HHV-7 infekcijas noteikšanai un apstiprināt to reproducējamību dažādās laboratorijās. Tika izvērtēta sešu iepriekš publicētu HHV-6 specifisku $P C R$ un četru HHV-7 specifisku $P C R$ jutība. Visjutīgākā HHV-6 noteikšanai izrādījās $P C R$ ar praimeriem, kas komplementāri Bgp071 gēnam un kas ḷāva noteikt piecas HHV-6 A un B tipa genoma kopijas. Pārējo HHV-6 specifisko PCR jutība bija zemāka - 10, 25 vai 50 HHV-6 genoma kopijas. HHV-7 specifisko PCR ar praimeriem, kas komplementāri LTP un TPP gēniem, jutība bija piecas kopijas, bet ar praimeriem, kas komplementāri IE-A transaktivatoram un NPP gēnam - viena vīrusa genoma kopija. Visjutīgākā reproducējamā HHV-7 noteikšanas $P C R$ bija pēdējā, kas mērkēta uz NPP gēnu. Atlasīto HHV-6 un HHV-7 specifisko $P C R$ reproducējamība bija pārbaudīta piecās dažādās laboratorijās. Visās laboratorijās iegūtie rezultāti bija identiski, kas liecina, ka šīs PCR var tikt lietotas kā HHV-6 un HHV-7 infekcijas molekulārās diagnostikas metodes praktiskajā medicīnā. 